\title{
Return to Glory? Prospects of Iran's Hospitality Sector Post-Nuclear Deal
}

\author{
Abstract \\ This paper focuses on the prospects of Iran's hospitality sector following Iran's recently \\ forged nuclear agreement (14 July 2015). The findings of this research shows that after years \\ of stagnation and decline Iran's hospitality sector is set to prosper from the softening of \\ relations with the west and easing of international sanctions. A number of international \\ chains including; Accor, Meliá Hotels International and Rotana Group have already entered \\ the Iranian market following the agreement with more expected to enter within the next a few \\ years. The findings also show that there is a renewed interest in the development of the \\ tourism industry in Iran with more than 100 hospitality outlets expected to open during the \\ coming five years.
}

Key words: Destination development; hospitality; Iran tourism; Iran nuclear; tourism development

\section{Introduction}

Iran is a country with enormous tourism potentials. Iran attracts a diverse tourist base, including young adventurers as well as older, more experienced travellers. Its strategic location - situated in the Middles East and close to Asia - creates strong cultural links to both regions with an important geopolitical position (Euromonitor, 2015). The recent nuclear agreement - reached in Vienna on 14 July 2015 - and the subsequent softening of relations with the west has given many, both inside and outside of Iran, the hope of a brighter future for the country (Khodadadi, 2016). The UK's Guardian newspaper ranking the country number 6 on its 'Holiday hotspots: where to go in 2016' list. However, over the past three decades, tourism industry in Iran has faced a number of challenges mostly due to international - nuclear related - sanctions. Iran was considered to be the Middle East's top tourist destination during the period 1967-1977 and many international firms such as InterContinental, Hyatt and Hilton had hotels in the country (Euromonitor, 2015; Porter, 2016). But they were replaced 'with relatively drab government-sanctioned accommodation' as sanctions were placed on the country and Western companies left (Porter, 2016). 


\section{Brief Background to Iran's Hospitality Sector}

Hospitality is a phenomenon that is deeply rooted in the Iranian culture and history (Khodadadi \& O’Donnell, 2015). O’Gorman (2007, p. 31) for instance argues that 'Iran is an incredibly diverse country that is rich in cultural and historic terms, representing a recorded human history that stretches back some 10,000 years. There is considerable evidence for commercial hospitality that dates back to at least 2000bc'. This is very much due to Iran's historically strategic location along the Silk Route. This ancient route 'is one of the best known of the world's historical trading routes, traditionally running from Xian in Northern China through Iran and on to Istanbul' (O’Gorman, 2009, p. 785). Iran’s location - situated between the Ottoman and Mughal empires and commercial hospitality - facilitated trade and pilgrimage throughout the surrounding regions (Bryce et al., 2013, p. 205). Commercial hospitality existed in the form of Caravanserais which were 'hostels for travellers, where accommodation was often provided free for a night. A comprehensive system of caravanserai existed across Iran, and wider Islamic world’ (Bryce et al., 2013, p. 205).

However, despite being referred to as one of the origins of commercial hospitality (O’Gorman, 2009), over the past three decades 'Iran had disappeared from the international tourism map' (Euromonitor, 2015, p. 17). The sudden revival in the industry - as a result of the recently forged nuclear agreement - has caught many of the suppliers unprepared. Therefore, the industry faces shortage of rooms, and is dominated by local independent chains which often lack the necessary international quality standards (Euromonitor, 2015). According to the same source the number of hotel outlets in Iran stands at 753 in 2014 with sales value of IRR 3,113.7 billion (Table 1).

\begin{tabular}{|l|c|c|c|c|c|c|}
\hline & $\mathbf{2 0 0 9}$ & $\mathbf{2 0 1 0}$ & $\mathbf{2 0 1 1}$ & $\mathbf{2 0 1 2}$ & $\mathbf{2 0 1 3}$ & $\mathbf{2 0 1 4}$ \\
\hline Units & 667 & 685 & 703 & 725 & 747 & 753 \\
\hline $\begin{array}{l}\text { Sales } \\
\text { IRR billion }\end{array}$ & $1,785.7$ & $1,802.1$ & $1,821.7$ & $1,837.9$ & $2,550.4$ & $3,113.7$ \\
\hline
\end{tabular}

Table 1. Hotel Outlets: Units and Sales 2009-2014

Source: Euromonitor International (2015, p. 19) 


\section{The Iran Nuclear Deal and the Future of the Hospitality Sector}

The hotel sector in Iran has been dominated by the local players since the closure of most international chains following the 1979 Iranian revolution. However, after the 14 July 2015 nuclear agreement optimism about the industry's prospects began to arise (Khodadadi, 2016). As a result, a number of international chains are beginning to show a renewed interest in Iran. For instance, the UAE's Rotana Group is set to open three new outlets within two to three years. This could place increasing pressure on local independent hotels, most of which require revamping and improvements (Euromonitor, 2015). On the other hand, this could also encourage these businesses to invest in quality in order to be able to cope with increased competition. Bozorgmehr (2015) of the UK's Financial Times claims that France's Accor is also set to take over two hotels in Iran and wants to 'secure at least 100 more over the next decade, as a breakthrough nuclear deal with world powers paves the way for a boost in the country’s untapped hospitality sector'.

According to Euromonitor (2015) more than 100 outlets are expected to open during the coming five years. Two of Iran's biggest cities - Tehran and Mashhad - are expected to be the main cities targeted for developments. This is due to Tehran's position as the leading business tourism destination in the country and Mashhad - housing the tomb of Imam Reza, the eighth Shia Imam - hosting millions of pilgrims every year.

Another development for the sector is the announcement that Meliá hotels group will open Iran’s first new five-star hotel owned by a foreign group. The ‘Gran Meliá Ghoo’ hotel (Figure 1) will open next year in the city of Salman Shahr on the shores of the Caspian Sea. 


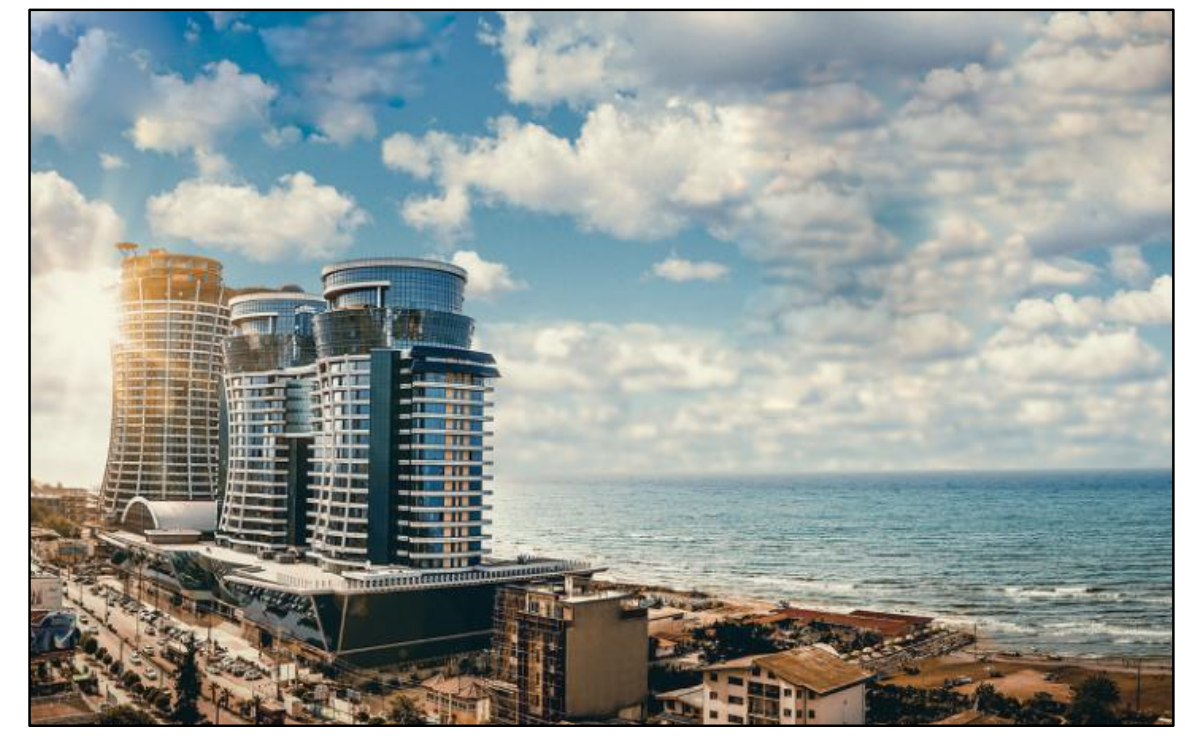

Figure 1: “Gran Meliá Ghoo”, Iran

Source: Meliá Hotels International (2016)

Meliá Hotels International is one of the 'largest hotel companies in the world and the largest hotel chain in Spain in both resort and city hotels. The company currently operates more than 350 hotels in 35 countries and 4 continents’ (Meliá Hotels International, 2016). It has properties in destinations from 'Tenerife to Thailand and is the first hotel group from outside Iran to open a five-star property in the country in more than 35 years' (Porter, 2016). According to the company,

The Gran Meliá Ghoo Hotel will occupy a 130-metre high tower and will provide 319 deluxe rooms of different types, one of them a Presidential Suite measuring more than $500 \mathrm{~m} 2$. The hotel will provide all of the luxury services and facilities expected of a five-star hotel, including seven restaurants and bars, over 1,300 m2 of meeting and banquet facilities, two swimming pools, a spa, and diverse leisure and shopping facilities (Meliá Hotels International, 2016).

It is evident that the Iranian government's attitude towards tourism development in Iran has also changed. In an interview with the Associated Press, Iran's vice president told the news agency that the country is preparing for a 'tsunami' of foreign tourists as the sanctions are lifted (Dareini, 2015). According to the same source 'Iran aims to host 20 million tourists a year by 2025, with expectations of growing the tourist industry to $\$ 30$ billion’ (Dareini, 2015). In the interview with the AP, Mr Soltanifar, who is also Iran's Cultural Heritage, Handicrafts and Tourism Organization chief claims that 'We need to increase our four and 
five star hotels from 130 to 400 in 10 years. We are providing low-interest funds out of the National Development Fund to private investors to build modern hotels’ (Dareini, 2015). Euromonitor (2015) also forecast that the number of hotel outlets in Iran is due to increase from 753 in 2014 to 863 in 2019 and sales from 3,113.7 IRR billion to 3,830.4 IRR billion (Table 2).

\begin{tabular}{|l|c|c|c|c|c|c|}
\hline & $\mathbf{2 0 1 4}$ & $\mathbf{2 0 1 5}$ & $\mathbf{2 0 1 6}$ & $\mathbf{2 0 1 7}$ & $\mathbf{2 0 1 8}$ & $\mathbf{2 0 1 9}$ \\
\hline Units & 753 & 768 & 787 & 809 & 835 & 863 \\
\hline $\begin{array}{l}\text { Sales } \\
\text { IRR billion }\end{array}$ & $3,113.7$ & $3,228.5$ & $3,353.3$ & $3,491.9$ & $3,652.8$ & $3,830.4$ \\
\hline
\end{tabular}

Table 2. Forecast Hotel Outlets: Units and Sales 2014-2019

Source: Euromonitor International (2015, p. 19)

A further testament that there is a renewed interest in the development of the tourism industry in Iran with more than 100 hospitality outlets expected to open during the coming five years.

\section{Conclusion}

For now, it seems that the recently forged nuclear agreement and the subsequent softening of the relations with west has crated unique opportunities for the struggling hospitality sector in Iran. It is clear that foreign investors are keen to explore Iran's untouched market as 'Iran will be the largest economy to re-enter international markets since the fall of the Soviet Union' (Murphy, 2016). However, we should also not forget that tourism infrastructure is relatively underdeveloped in Iran and suffers from poor service quality at hotels and other service providers within the sector (Euromonitor, 2015). Iran is also having complicated relations with the West and suffers from negative imagery in the western media which portray the country as dangerous and inhospitable (Khodadai \& O’Donnell, 2015). Hence, there is still some way to go for the country to become a key player in the region.

\section{References}

Bryce, D. O’Gorman, K. D. \& Baxter, I. (2013). Commerce, empire and faith in Safavid Iran: the caravanserai of Isfahan. International Journal of Contemporary Hospitality Management, 25 (2), 204-226. DOI: http://dx.doi.org/10.1108/09596111311301603 
Bozorgmehr, N. (2015, September 15). Accor books a place in Iran's hotel sector. The Financial Times. Retrieved from http://www.ft.com/cms/s/0/827d3bce-5ba9-11e5-9846de406ccb37f2.html\#axzz453pNnIGx

Dareini, A. A. (2015, October 18). AP Interview: Iran preparing for "tsunami” of tourists, Associated Press. Retrieved from http://bigstory.ap.org/article/35ac9e6ebfd346da9c3c19a78e16cb3b/ap-interview-iranpreparing-tsunami-tourists

Euromonitor International. (2015). Travel and tourism in Iran report. Retrieved from https://www.portal.euromonitor.com/

Khodadadi, M. \& O’Donnell, H. (2015). UK press and tourist discourses of Iran: a study in multiple realities, Leisure Studies, DOI: http://dx.doi.org/10.1080/02614367.2015.1085591

Khodadadi, M. (2016). A new dawn? The Iran nuclear deal and the future of the Iranian tourism industry. Tourism Management Perspectives, 18, 6-9. DOI: http://dx.doi.org/10.1016/j.tmp.2015.12.019

Meliá Hotels International. (2016, March 02). Meliá Hotels International announces its first Gran Meliá hotel in Iran alongside a leading Iranian industrial \& developer group. Retrieved from http://www.meliahotelsinternational.com/en/pressroom/03022016/melia-hotels-international-announces-its-first-gran-melia-hotel-iranalongside

Murphy, H. (2016, January 29). Iran is back in business. The Financial Times. Retrieved from http://www.ft.com/cms/s/0/325fdf4a-bec6-11e5-846f79b0e3d20eaf.html\#axzz43p26jEiy

O’Gorman, K. D. (2007). Iranian hospitality: a hidden treasure. The Hospitality Review, 9 (1), 31-36.

O'Gorman, K. D. (2009). Origins of the commercial hospitality industry: from the fanciful to factual, International Journal of Contemporary Hospitality Management, 21 (7), 777790, DOI: http://dx.doi.org/10.1108/09596110910985287

Porter, L. (2016, March 03). The luxury hotels luring western tourists to Iran. The Telegraph. Retrieved from http://www.telegraph.co.uk/travel/destinations/middleeast/iran/articles/melia-to-open-irans-first-international-five-star-hotel/ 